\title{
過小応力を含むプログラム荷重下 における低炭素鋼の疲労寿命*
}

\author{
山田敏 郎** 幡中憲治** \\ 近藤幸 *** 河 合 宏 $^{* * * *}$
}

\author{
Fatigue Life of Low Carbon Steel under Programmed Loading \\ Including Stress Lower than Fatigue Limit
}

by

\author{
Toshiro Yamada, Kenji Hatanaka, Yukio Kondo \\ (Faculty of Engineering, Kyoto University, Kyoto) \\ and Hiroshi KaWAI \\ (Nippon Kokan Ltd., Shimizu)
}

\begin{abstract}
The manifold repeated rotating bending fatigue tests are carried out at two stress levels on three low carbon steels, which are rimmed, Si-killed and Al-killed steels having the different ageing abilities. These tests constitute a characteristic feature that the cumulative frequency of programmed loading cycles is mainly occupied by the understress lower than the fatigue limit.

The fatigue life under programmed loading is plotted against the equivalent stress, which is estimated on the basis of the modified Miner's law, both on $\log -\log$ and semi-log diagrams. All experimental points of rimmed steel fall on the right side of the straight line extrapolated from the linear part of $S-N$ curves on both diagrams. Those of Si-killed and Al-killed specimens seem to lie mostly around the above extrapolated straight line, but some experimental points in the longer life range tend to deviate from the straight line toward the shorter life direction on log-log diagram.

The cumulative cycle ratios based on Miner's law are mostly larger than one in rimmed steel, while in Si-killed and Al-killed steels the greater part of these values are less than one. These facts indicate that in the former the understress contributes to the increase of fatigue strength for the higher stress above the fatigue limit, while in the latter it gives fatigue damage to the specimen.

The results of surface structure observation and hardness measurement in the fatigued specimen suggest that the strain ageing gives a remarkable effect on fatigue strength. The fatigue test results mentioned above can be explained along this line.
\end{abstract}

(Received Feb. 17, 1976)

\section{1 緒言}

一般の機械構造物に作用する繰返し応力は疲労限度 以下の応力（過小応力）が大部分で疲労限度を越光る 応力（過大応力）の繰返しは少ないのが普通である.

多段多重疲労試験結果は過小応力の繰返しが多い場合 にはこれが疲労寿命を短くしたり，長くしたりする場 合のあることを示している。また繰返し応力は被害と 強化の両作用をるっでらり, 試験条件に上り被害が大 きければ材料は破壞し, 強化作用が大きければ破断に

\footnotetext{
* 原稿受理 昭和51年 2 月17日

** 正 会 員 京都大学工学部 京都市左京区吉田本町

*** 京都大学工学部 京都市左京区吉田本町

**** 日本鋼管(株) 清水市三保
}

はいたらないものと考えられる. 他方, 疲労過程中の ひずみ時効や加工硬化は coaxing 効果として知られ て扣り，これは疲労強度にかなり大きな影響を与える。 とくに疲労限度は繰返し応力中のひずみ時効によると ころが大きく, またひずみ時効が疲労強度を増加させ る等の現象が明らかにされている.

したがって過小応力の効果に材料の時効性が影響す ることが予想されるので, 本研究では時効性の異なる 3 種の低炭素鋼を用いて二段多重プログラム疲労試験 を行ない, 過大応力と過小応力が疲労強度に及ぼす影 響について検討したのでその結果を報告する。

\section{2 試料および実験方法}

供試材は, リムド鋼, Si-キルド鋼および $\mathrm{Al}$ おキル 
Table II. Condition of heat treatment for test materials.

\begin{tabular}{|c|c|}
\hline Materials & Heat treatment \\
\hline Rimmed steel & 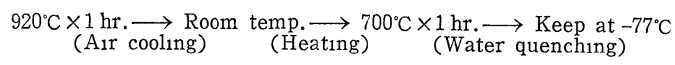 \\
\hline Si-killled steel & $\begin{array}{l}920^{\circ} \mathrm{C} \times 1 \text { hr. } \longrightarrow \text { Room temp. } \\
\text { (Air cooling) }\end{array}$ \\
\hline Al-killed steel & 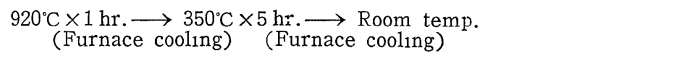 \\
\hline
\end{tabular}

Table I. Chemical composition of materials used.

\begin{tabular}{|c|c|c|c|c|c|c|}
\hline Materıals & C & $\mathrm{Si}$ & $\mathrm{Mn}$ & $\mathrm{P}$ & S & $\mathrm{A} 1$ \\
\hline Rimmed steel & 0.11 & 001 & 0.39 & 0.016 & 0018 & - \\
\hline Si-killed steel & 012 & 0.24 & 042 & 0022 & 0015 & 0.006 \\
\hline Al- killed & 0.09 & 003 & 0.46 & 0013 & 0.016 & 0031 \\
\hline
\end{tabular}

Table III. Mechanical properties of materials used.

\begin{tabular}{c|r|r|r|r|r}
\hline Materials & $\begin{array}{l}\text { Lower } \\
\text { yield } \\
\text { point } \\
\left(\mathrm{kg} / \mathrm{mm}^{2}\right)\end{array}$ & $\begin{array}{c}\text { Tensile } \\
\text { strength } \\
\left(\mathrm{kg} / \mathrm{mm}^{2}\right)\end{array}$ & $\begin{array}{c}\text { Elongation } \\
(\%)\end{array}$ & $\begin{array}{c}\text { Fracture } \\
\text { duct1lity } \\
(\%)\end{array}$ & $\begin{array}{c}\text { Area } \\
\text { contrac- } \\
\text { tion } \\
(\%)\end{array}$ \\
\hline $\begin{array}{c}\text { Rimmed } \\
\text { steel }\end{array}$ & 23.7 & 41.4 & 31.5 & 1356 & 742 \\
$\begin{array}{c}\text { Si-killed } \\
\text { steel }\end{array}$ & 256 & 40.0 & 35.5 & 1265 & 718 \\
$\begin{array}{c}\text { Al-kiled } \\
\text { steel }\end{array}$ & 21.3 & 33.1 & 40.3 & 135.8 & 743 \\
\hline
\end{tabular}

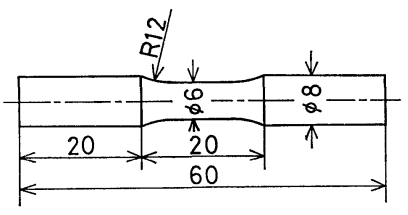

Fig. 1. Shape and sizes of test specimen.

ド鋼で疲労部門委員会の共同研究用として準備された ものである. その化学成分を Table I に示す. 一般 に時効性はリムド鋼, $\mathrm{Si}$-キルド鋼, $\mathrm{Al}$-キルド鋼の順 に大であるがさらにその傾向を大にするため，また結 晶粒径を揃えるために Table II に示す熱処理を施し た. 各材料の機械的性質を Table III に示す. 試験 片は機械加工後, 熱処理を施し, その表面を0/5エメ リ一紙にて研摩後, 電解研摩により鏡面に仕上げた。 なおその形状・寸法を Fig. 1 に示す.

疲労試験は小野式回転曲げ試験機 (3000 r. p. m.) に 荷重変動装置を設置して行なった. 荷重変動プログラ ムは二段多重とし (Fig. 2), 一次応力 $\sigma_{1}$ として過小 応力（それぞれの材料の疲労限度の $90,70,50$ 打よび $30 \%$ )，二次応力 $\sigma_{2}$ として過大応力（それぞれ繰返し 数 $N_{f} \cong 4 \times 10^{5}$ で破断すると考学られる応力で, リム

ド鋼 : $1.18 \sigma_{w}, \mathrm{Si}$-キルド鋼 : $1.25 \sigma_{w}, \mathrm{Al}$-キルド鋼 $\left.: 1.33 \sigma_{w}\right)$ を採用した. $n_{1}, n_{2}$ は過小応力, 過大応 力の 1 ブロック中の繰返し数である.これらの值を Table IV に合わせて示す.

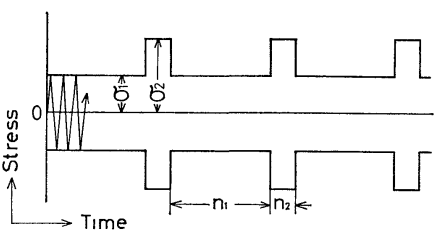

Fig. 2. Stress pattern for programmed loading.

Table IV. Values of $\sigma_{1}, \sigma_{2}, n_{1}$ and $n_{2}$ in programmed loading fatigue test.

\begin{tabular}{|c|c|c|c|c|c|c|c|}
\hline \multirow[b]{2}{*}{$\sigma_{1}\left(\mathrm{~kg} / \mathrm{mm}^{2}\right)$} & \multicolumn{2}{|c|}{ Rımmed steel } & \multicolumn{4}{|c|}{ Si-k1lled steel } & A1-k1lled steel \\
\hline & \begin{tabular}{l|l}
6.6 & 11
\end{tabular} & 15.4198 & 6 & 10 & 14 & 18 & \begin{tabular}{ll|l|l|l}
4 & 5 & 75 & 10 & 5
\end{tabular} \\
\hline$\sigma_{2}\left(\mathrm{~kg} / \mathrm{mm}^{2}\right)$ & \multicolumn{2}{|c|}{26} & \multicolumn{4}{|c|}{25} & 20 \\
\hline$n_{1}$ & \multicolumn{7}{|c|}{$3.569 \times 10^{5}$} \\
\hline$n_{2}$ & \multicolumn{7}{|c|}{$8.9 \times 10^{3}$} \\
\hline
\end{tabular}

\section{3 実験結果および考察}

\section{$3 \cdot 13$ 種の材料の時効性}

これらの材料の時効性を, 実際に降伏点の回復能力 により調べた. $4 \%$ の予ひずみ（引張応力 $\sigma_{Y}$ ）を与 えた後, $60^{\circ} \mathrm{C} \times 72$ 時間の時効処理を行ない, 時効処理 後の下降伏点を $\sigma$, そして $\sigma-\sigma_{Y}=\Delta \sigma_{Y}$ とするとき, 式 $R=\Delta \sigma_{Y} / \sigma_{Y}$ によって求めた $R$ の值は, リムド鋼の 場合 $0.16, \mathrm{Si}$-キルド鋼で 0.12 そして $\mathrm{Al}$-キルド鋼で は0.06になった.これよりこれらの材料はリムド鋼, $\mathrm{Si}$-キルド鋼， $\mathrm{A} 1$-キルド鋼の順にひずみ時効性が大 きく，これら 3 種の材料は本研究の目的に適するもの である。

\section{$3 \cdot 2$ 疲労試験結果}

Fig. 3 は一定繰返し応力下で得られた $S-N$ 曲線特 よび変動荷重疲労試験結果を次式に示す等価応力 $\sigma_{e q}{ }^{6}$ を用いて整理し，それぞれ，(a)片対数グラフ上，(b)両 対数グラフ上に整理した結果である. この $\sigma_{e q}$ はいず れも修正マイナー則により算出されたものであって $\sum n / N=1$ で破壊する場合は, $\left(\sigma_{e q} \cdot N_{f}\right)$ の点は元の $S-N$ 曲線の直線部の延長線上に乗る. この場合の総繰 返し数は過小応力および過大応力の繰返し数を加えた 総繰返し数 $\sum n_{\imath}$ で表わした.

片対数表示の場合 


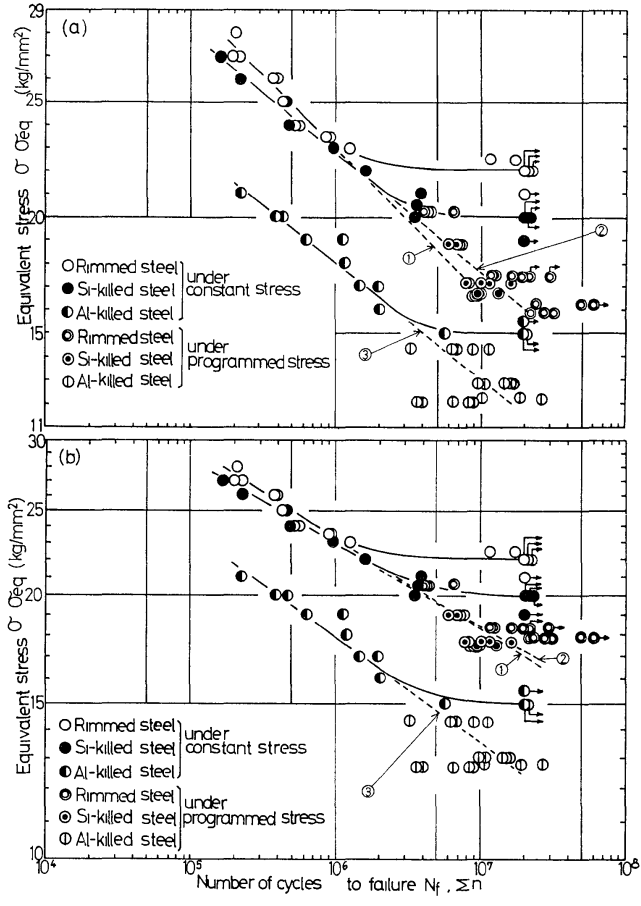

(a) On semi-log basis

(b) On $\log -\log$ basis

Fig. 3. $S-N$ curves and $\sigma_{e q} v s$. $\Sigma n$ plot of test results under programmed loading.

$$
\sigma_{e q}=a \ln \frac{\sum e^{\sigma_{i} / a} \cdot n_{\imath}}{\sum n_{\imath}}
$$

ただし， $S-N$ 曲線の直線部を $\sigma=-a \ln N+b$ で 表示する.

両対数表示では

$$
\sigma_{e q}=\sqrt[m]{\frac{\sum \sigma_{\imath}{ }^{m} \cdot n_{\imath}}{\sum n_{\imath}}}
$$

ただし， $S-N$ 曲線の直線部を $\ln \sigma=-(1 / m) \ln N$ $+C$ で表示する.

ここで $\sigma_{\imath}$ は各荷重変動レベルでの応力振幅, $n_{\imath}$ は 荷重変動の 1 ブロック中の $\sigma_{2}$ の繰返し数である.

一定繰返し応力下で得られた $S-N$ 曲線を比較する と顕著な時効性を示すリムド鋼の限界繰返し数は時効 性の小なる $\mathrm{Si}$-キルド鋼および $\mathrm{Al}$-キルド鋼のそれよ り小さいことがわかる.

変動荷重疲労試験には一組の疲労試験に対して 3 5 本の試験片を用いた. またリムド鋼の場合，過大応 力 $1.18 \sigma_{w}$, 過小応力 $0.7 \sigma_{w}$ で繰返し数 $N=2.2 \times$ $10^{7}$ 以上执よ゙同じ過大応力で過小応力 $0.5 \sigma_{w}$ で $N=$ $6 \times 10^{7}$ で破断しなかったものはその時点で疲労試験 を中止した（図中に矢印で示す），破断時の応力レベ ルは過大応力の場合もあり過小応力の場合もあって必 ずしも一定していない. しかし過小応力の低下につれ 過大応力の繰返し中に破断する傾向が増大した.
Fig. 3 (a)，(b)より，いずれの材料についても過小応 力が $0.9 \sim 0.5 \sigma_{w}$ の範囲内では過小応力の減少につれ て破断までの総繰返し数 $\left(\sum n_{\imath}\right)$ は増加するが，過小 応力が $0.3 \sigma_{w}$ の場合には総繰返し数は減少すること がわかる。

リムド鋼の変動荷重疲労試験結果（以下これを試験 寿命という） はすべて片対数表示，両対数表示いず れの表示法に対しても元の $S-N$ 曲線の直線部(1)より も長寿命側にずれることが明らかである。また Si-キ ルド鋼扣よび Al一キルド鋼の場合には過小応力 $\sigma_{1}$ が $0.9 \sim 0.5 \sigma_{w}$ の範囲内では, 片対数表示による試験寿 命はほぼ上記直線部(2)，(3)に乗り，いわゆる修正マイ ナー則が成立するようである，そして両対数表示では これらの試験寿命は短寿命側にずれる傾向がある。ま た過小応力が $0.3 \sigma_{w}$ の場合には試験寿命はいずれの 表示法に対しても計算寿命より短寿命となっている.

疲労試験結果を修正マイナー則を用いた等価応力に より両対数グラフ上に整理する場合, 過小応力が 0.7 $\sim 0.3 \sigma_{w}$ の範囲内では等価応力值は非常に接近する.

これは過小応力の効果が充分にとり入れられていない ことを示して和り，このよらな場合には両対数表示は 適当ではないことを示している.

上記変動荷重下の疲労試験結果について修正マイナ 一則による累積繰返し数比 $\left(\sum n_{\imath} / N_{\imath}\right)$ を計算し, これ を Table V に示す. 累積繰返し数比は, リムド鋼で はすべて 1 以上, 一方, $\mathrm{Si}$-キルド鋼および $\mathrm{A} 1$-キル ド鋼では大半が 1 以下である.これより過小応力によ る被害はリムド鋼よりも $\mathrm{Si}$-キルド鋼抢よび $\mathrm{Al}$ 一キル ド鋼において顕著である.

$\mathrm{Si}$-キルド鋼， $\mathrm{A} 1$-キルド鋼で過小応力が $0.3 \sigma_{w}$ の とき，試験寿命が計算寿命よりも短くなったことより， 過小応力の繰返しによる材料の強化作用に対しては, 過小応力であってもあるレベル以上の応力の繰返しが 必要であることがわかる. $0.3 \sigma_{w}$ はこのレベル以下 の応力に対応していたことに起因していると思われる。 またこれより変動荷重の場合は過大応力により被害が 与えられると過小応力でも被害が発生することがわか る.

一方, マイナー則により求めた累積繰返し数比 $\left(\sum\right.$ $\left.n_{2} / N_{2}\right)$ は, リムド鋼では過小応力が $0.9 \sigma_{w}$ の場合を 除いて匡とんど 1 以上となり，これは過小応力が 0.7 $\sim 0.3 \sigma_{w}$ の範囲内では過小応力の繰返しにより材料 は強化されたことを示す. 他方 $\mathrm{Si}$-キルド鋼, $\mathrm{Al}$-キ ルド鋼では累積繰返し数比の大部分が 1 以下となり， 過小応力による被害が生じることを示している.

また，変動荷重疲労試験（過小応力がそれぞれ $0.3 \sigma_{w}$ で, 過大応力がリムド鋼 : $1.18 \sigma_{w}, \mathrm{Si-キルド}$ 鋼 : $1.25 \sigma_{w}, \mathrm{Al}$-キルド鋼 : $1.33 \sigma_{w}$ ) の後, 試験片表 
Table V. Test results under programmed loading

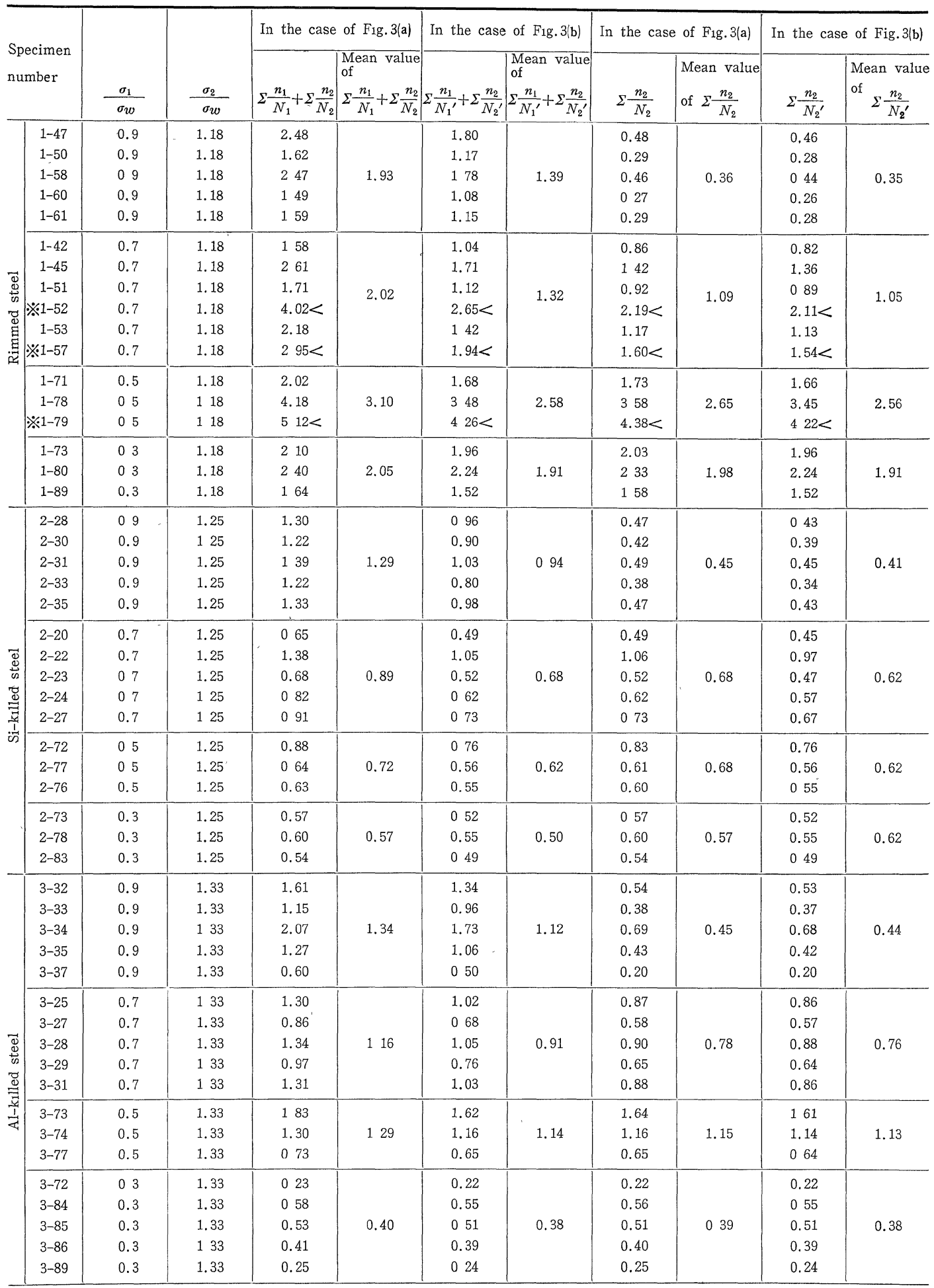

$※$ Unfailure

$N_{1}$ and $N_{2}$ are number of cycles to fallure at $\sigma_{1}$ and $\sigma_{2}$ on $S-N$ curve plotted on semi-log basis.

$N_{1}^{\prime}$ and $N_{2}^{\prime}$ are number of cycles to fallure at $\sigma_{1}$ and $\sigma_{2}$ on $S-N$ curve plotted on $\log -\log$ basis. 
面の硬度をマイクロ・ビッカース硬度計（測定荷重 $100 \mathrm{~g}$ ，保持時間 30 秒）にて測定した。 そ結果, 時 効性の大きいリムド鋼の場合には硬度が最初 111 あっ たものが 207 に，Si-キルド鋼では 117 から 149 に， Al一キルド鋼では 94 から 106 へとそれぞれ硬度が上昇 した.この事実は過小応力含告変動荷重下の材料の 強化が，その材料の時効性に影響を受けることを示し て特り、これはまた Fig.3 の実験結果に対する本論 文の考察を裏付けるものである.

\section{$3 \cdot 3$ 光学顕微鏡による表面観察}

Fig. 4 は変動荷重疲労試験結果の一例で, それぞれ 過小応力が $0.7 \sigma_{w}$ の場合である.な就この場合の荷 重変動パターンは次のようにした。すなわち1ブロッ ク走 $\sigma_{1}$ の $10 n_{1}$ 回と $\sigma_{2}$ の $10 n_{2}$ 回之から構成した。 そして写真撮影は繰返乙数 $N=0,10 n_{1}, 10 n_{1}+10 n_{2}$, $20 n_{1}+10 n_{2}, 20 n_{1}+20 n_{2}\left(0,3.569 \times 10^{6}, 3.658 \times 10^{6}\right.$, $7.227 \times 10^{6}, 7.316 \times 10^{6}$ 回) の五つの疲労過程に対し て行なった，Fig.4 (a),(e)に示すようにリムド鋼，A1キルド鋼ともに 1 回目の過小応力の繰返し $\left(10 n_{1}\right.$ 回) ではすべり線は発生しない. 1 回目の過大応力る負荷 する $\left(10 n_{1}+10 n_{2}\right.$ 回)ことによりすべり線が発生する.
2 回目の過小応力の繰返し $\left(20 n_{1}+10 n_{2}\right.$ 回) ではすべ り線の增加はほとんど認められない。として2回目の 過大灾力を負荷する $\left(20 n_{1}+20 n_{2}\right.$ 回) と, 時效性を示 すリムド鋼ではすべり線の状態にはほとんど変化は認 められなかったが，時効性の小さい $\mathrm{Al}$ 小ルド鋼では すべり線は增加した。李た Si一キルド鋼は $\mathrm{A} 1$-キルド 鋼とほぼ同様のすべり線の形態の变化を示した。これ は顕著な時効性を示すリムド鋼では 2 回目の過小応力 の繰返し中に過大応力により発生したすべり線部分に 存在する転位が時效硬化により次第に固着され強化さ れるためと考壳られる.

この表面観察の結果と $3 \cdot 2$ 節の変動荷重疲学試験 後の硬度測定の結果を合わせて考えると顕者な時効性 を示すリムド鋼では，過小応力の繰返し中にひずみ時 效, 加工硬化による材料の強化が起こる. そしてこの ことは Table V に拈ける修正マイナー則による累積 繰返し数比が 1 より大きくなることと刘応するるのと 考えられる. 一方時効性の小さい Al一キルド鋼では過 小応力の繰返し中に上記強化が起こりにくいため,

Fig. 4 (h)に示すようなすべり線の増加が認められ，か つ Table V から明らかなように過小応力は被害作用
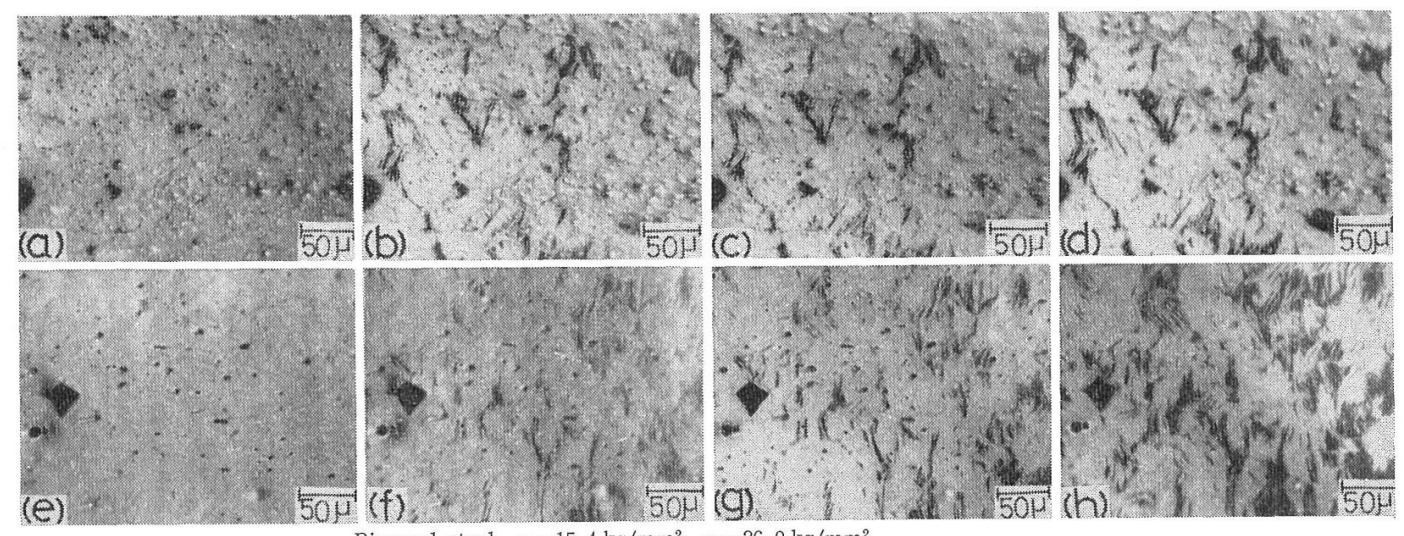

Rimmed steel $\sigma_{1}=15.4 \mathrm{~kg} / \mathrm{mm}^{2} \quad \sigma_{2}=26.0 \mathrm{~kg} / \mathrm{mm}^{2}$

$\begin{array}{llll}\text { (a) } 10 n_{1} & \text { (b) } 10 n_{1}+10 n_{2} & \text { (c) } 20 n_{1}+10 n_{2} & \text { (d) } 20 n_{1}+20 n_{2}\end{array}$

Al-killed steel $\quad \sigma_{1}=10.5 \mathrm{~kg} / \mathrm{mm}^{2} \quad \sigma_{2}=20.0 \mathrm{~kg} / \mathrm{mm}^{2}$
(e) $10 n_{1}$
(f) $10 n_{1}+10 n_{2}$
(g) $20 n_{1}+10 n_{2}$
(h) $20 n_{1}+20 n_{2}$

Fig. 4. Surface structure changes during programmed loading.

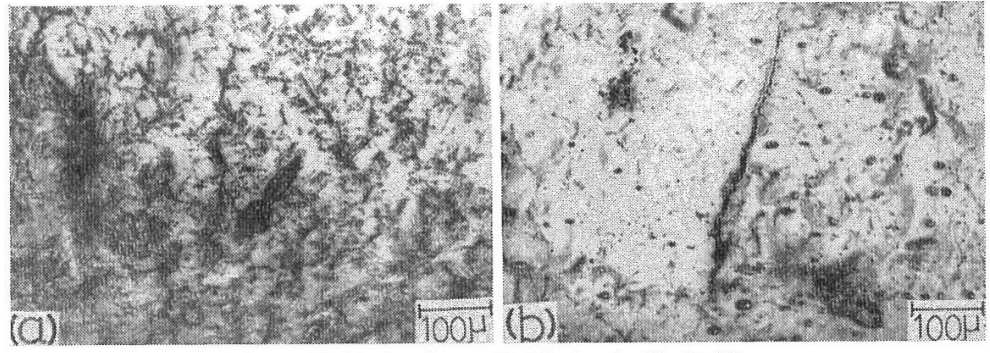

(a) $\sigma_{1}=15.4 \mathrm{~kg} / \mathrm{mm}^{2} \quad \sigma_{2}=26.0 \mathrm{~kg} / \mathrm{mm}^{2} \quad N=3 \times 10^{7}$

(b) $\sigma_{1}=11.0 \mathrm{~kg} / \mathrm{mm}^{2} \quad \sigma_{2}=26.0 \mathrm{~kg} / \mathrm{mm}^{2} \quad N=6 \times 10^{7}$

Fig. 5. Crack observed in rimmed steel specimens which survived under programmed loading. 
を有するものと考えられる.

Fig. 5 は変動荷重疲労試験を行なった際の未破断の リムド鋼試験片（(a)過小応力: $0.7 \sigma_{w}, \quad N=3 \times 10^{7}$, (b)過小応力: $0.5 \sigma_{w}, \quad N=6 \times 10^{7}$, いずれも過大応力 $\left.1.18 \sigma_{w}\right)$ の表面を電解研摩により $2 \sim 3 \mu$ 除去した後 に観察されたき裂である.Fig. 4 で示した表面のすべ り線の観察結果では 2 回目の過大応力ではすべり線形 態の変化は至とんど羿められなかった。 しかし Fig.5 に示すように多数回の過大応力の繰返しによりかなり 大きいさ裂（(a)約 $0.25 \mathrm{~mm}$ ，(b)約 $0.5 \mathrm{~mm}$ ） が発生 することがわかる.したがってこれらの試験片はさら に繰返し応力を付与することにより破断にいたるるの と考えられる.

\section{4 結言}

大頻度の過小応力を含む二段多重プログラム疲労試 験を時効性の異なる 3 種の軟鋼材について実施し, 過 大応力拈よび過小応力が疲労強度に及ぼす影響につい て検討した。

（1）一定繰返し応力下で得られた $S-N$ 曲線を比較 すると限界繰返し数は顕著な時効性を示すリムド鋼で 最も小さく, この結果はいわゆる疲労限度の存在にひ ずみ時効が顕著な役割を果たしていることを暗示して いる.

（2）変動荷重疲労試験結果について修正マイナー則 を用いて寿命を計算し，これを等価応力を用いて表示 した.リムド鋼の場合, 実験点は片対数表示でも両対 数表示でも一定繰返し応力下で得られた $S-N$ 曲線の 直線部分の延長線より長寿命側に位置する. Si-キル ド鋼， $\mathrm{A} 1$-キルド鋼の片対数表示による結果はほぼ上 記延長線上に乗り，修正マイナー則が成立する。これ は過小応力による疲学被害が前者よりも後者に执いて
顕著であることを示している.

（3）両対数表示に执いて修正マイナー則を用いた等 価応力值は過小応力が $0.7 \sim 0.3 \sigma_{w}$ の範囲内では度と えど接近する.これは過小応力の効果が充分にとり入 れられていないことを示しており，両対数表示はこの 場合妥当ではないことを示している.

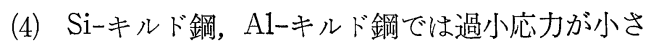
くなると $\left(0.3 \sigma_{w}\right)$, 試験寿命が計算寿命より短くなる. これは材料の強化作用に対しては過小応力であっても あるレベル以上の応力の繰返しが必要であることを示 している.

（5）変動荷重を受けた試験片の表面観察結果および 繰返し応力による硬度の測定結果は疲労過程にひずみ 時効が顕著な影響を与えることを示しており，これよ りひずみ時効の観点から変動荷重疲労試験結果を定性 的に説明することができる.

（6）とくに長寿命域に拈ける試験結果の整理に際し ては片対数表示法の方が両対数表示法より安全側の寿 命予測を与える.

(昭和50年11月21日 シンポジウム「疲労における最近の諸問題」にて 講演)

\section{参 考 文 献}

1）川田雄一, 三沢啓志, 材料, 17, 123 (1968).

2) 河本 実, 伊吹幸彦, 石川 浩, 材料, 17, 97 (1968).

3）長寿命疲れ強さ，日本機械学会関西支部シンポジウム資 料, 1 (1972).

4) Lipsitt, H. A., and G. T. Horne, Proc. ASTM, 57, 587 (1957).

5) 西谷弘信, 西田新一, 機械学会論文集, 39, 1385(1973).

6) 中村 宏, 堀川 武, 鎌田敬雄, 山地新一, 機械学会論 文集，39，472 (1973). 